\title{
Cooperatif Learning Models Simulation : From Abstract to Concrete
}

\author{
Ketut Agustini, ${ }^{1, *}$, and I Putu Wisna Ariawan ${ }^{2}$ \\ ${ }^{1}$ Teknologi Pembelajaran Pascasarjana, Universitas Pendidikan Ganesha, Jl. Udayana No. 11, \\ Singaraja, Bali. \\ ${ }^{2}$ Pendidikan Matematika, Universitas Pendidikan Ganesha, Jl. Udayana No. 11, Singaraja, Bali.
}

\begin{abstract}
This study aimed to develop a simulation of cooperative learning model that used students as prospective teachers in improving the quality of learning, especially for preparedness in the classroom of the microteaching learning. A wider range of outcomes can be used more widely by teachers and lecturers in order to improve the professionalism as educators. The method used is research and development (R\&D), using Dick \& Carey development model. To produce as expected, there are several steps that must be done through global research, among others, do steps (a) conduct in-depth theoretical study related to the simulation software that will be generated based on cooperative learning models to be developed, (b) formulate figure simulation software system is based on the results of theoretical study and (c) conduct a formative evaluation is done by content expert, design expert, and media expert to the validity of the simulation media, one to one student evaluation, small group evaluation and field trial evaluation. Simulation results showed that the Cooperative Learning Model can simulated three models by well. Student response through the simulation models is very positive by $60 \%$ and $40 \%$ positive. The implication of this research result is that student of teacher candidate can apply cooperative learning model well when teaching real in training school hence student need to be given real simulation example how cooperative learning is implemented in class.
\end{abstract}

Keywords: Simulation, Cooperative learning Models, formative evaluation, student responses

\section{Introduction}

The recognition of teacher status is very high and this is followed by a requirement of a teacher has four major competences, namely pedagogical, personal, social and professional competencies including also the beginning of prospective teachers preparation. Professional competence is the ability that consists of: mastery of the instructional materials, understanding of curriculum and its development, classroom management, use of

* Corresponding author: eghee2006@gmail.com 
strategies, media, and learning resources, has an insight into educational innovations, gives help and guidance to the students, etc. [1]

Teacher skills in managing classroom learning need to be improved by applying innovative learning models. Field findings show that not all teachers have implemented innovative learning models so that the learning process is less meaningful. This is also supported by the results of research [2] that ICT teachers tend not to utilize innovative learning models in classroom management so the class seems monotonous. The teacheres role not just as the one who transfers knowledge to the student, but as mediator and facilitator in learning [3].

Not only ICT teachers but most teachers in the class rarely use the varied learning and multimedia, because the students' success in understanding the basic concepts dependent on the degree of effectiveness of a lecturer in transferring his or her knowledge to the students using multimedia facilities [4].

There are many innovative learning models that have been applied to the current curriculum that require more active learners. One of the learning model is cooperative learning model. The cooperative learning model is one of the lessons developed from the theory of constructivism because it develops the cognitive structure to build its own knowledge through rational thinking [5].

The existence of cooperative learning model in education is not a new one [6]. However, in fact, in the field, there are still many educators who have not really known clearly the correct learning steps on various types of cooperative learning model that exists. In addition, many cooperative learning models confuse educators in distinguishing syntax and are considered still abstract and difficult considering the main characteristics or points that became the concept of each model of cooperative learning.

This is a challenge for the Instructional designer to provide intelligent solutions for the world of education, by visualizing an abstract into a concrete through the development of digital simulations, models of cooperative learning. By concretely it is something abstract that allows students to understand a concept and learning becomes more effective $[7,8]$. The specific purpose of this study is to develop a simulation system software that can be used to visualize cooperative learning models so as to help facilitate the understanding of educators, especially prospective teachers by looking, listening and certainly more easily understand the techniques and the main points that become Concepts of the various types of cooperative learning models available.

\section{METHOD}

The method used is research and development (R\&D), using Dick \& Carey development model. Software products generated from the development process are validated and tested through two testing stages: (1) Product testing techniques as a software, through SDLC standards with Waterfall-based Model, (2)Testing the product as an instructional system development, through Formative evaluation $[9,10]$.

The development of media begins with the need analysis for three dimensions, namely (1) the characteristics of cooperative learning model identify (2) choose the cooperative learning model that will be visualized; And (3) the syntax of the chosen learning model analysis. This needs analysis takes place continuously following the cycle, because the media will experience adjustments to change, needs, and trends. Then the fourth stage is the development design through standard SDLC with Waterfall Model.

Technical tests include testing software functionality performed in black box testing. Black box testing is the fundamental aspects testing of the system regardless of the internal 
logic structure of the software. This method is used to determine if the software is working properly. Black box testing is a method of designing test data based on software specification. Test data is generated, executed on the software and then the output of the software is checked whether it has been as expected. Software testing in this study concerns the following:

1. Step-by-step simulation (syntax) in each model;

2. Making figures in the simulation;

3. Description that corresponds to the model step;

4. Displaying simulated videos in the class

Meanwhile, the component of formative evaluation is done by content experts, media experts and design learning experts including the feasibility of content, language, appearance, and graph.

The revisions were made based on the evaluation results of content experts, media experts, and design learning experts. A limited trial was conducted on a small group of students to get a response to the simulation program. Data analysis for student response using questionnaires with Likert scale then analyzed descriptively qualitative.

\section{RESULT AND DISSCUSION}

The software functional model provides an overview of the processes that occur in the software without providing details on how these processes are implemented. Functional models also provide an overview of the flow of data that occurs between existing processes and between processes with external entities, such as software users. The flow of data will define the input and output contained in each process that occurs, so the relationship between processes can be seen clearly. The functional model used to describe this software is the Data Flow Diagram (DFD).

The context diagram is the level 0 DFD of the software. In the context, the diagram can be seen the interaction that occurs between users and software. There are three user input menu data required by the software. Next, from level 0 DFD elaborated to level 1 DFD, which explains in more detail the user input menus available in the system software. The design of the developed software interface screen, which consists of three choices of learning model menu, and other options menu, the description, and visualization area of the model in the form of simulation as well as the title and image area. Figure 1 shows the screen interface developed in the simulation model.

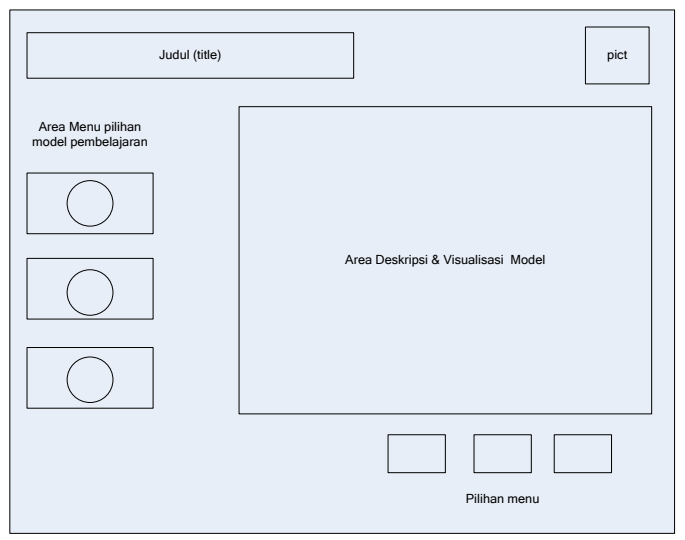

Figure 1. The Software Interface Screen Design. 
The software interface screen design is implemented using forms in the Macromedia Flash 8 implementation environment. Implementation of the main screen design of this software interface successively can be seen in the Fig. 2, Fig. 3, Fig 5 and Fig. 6 below.

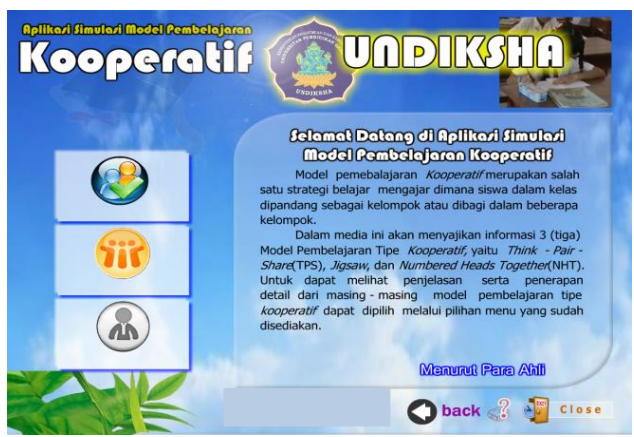

Figure 2. The Software Interface Screen Implementation.

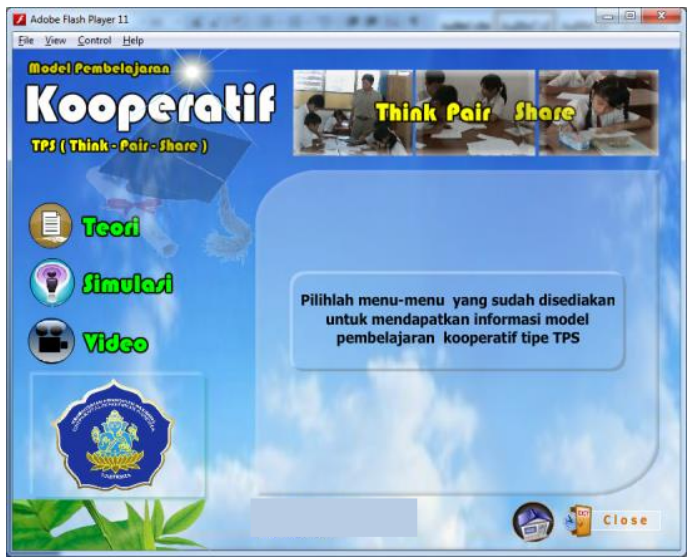

Figure 3. Optional menu on Think Pair Share model simulation interface.

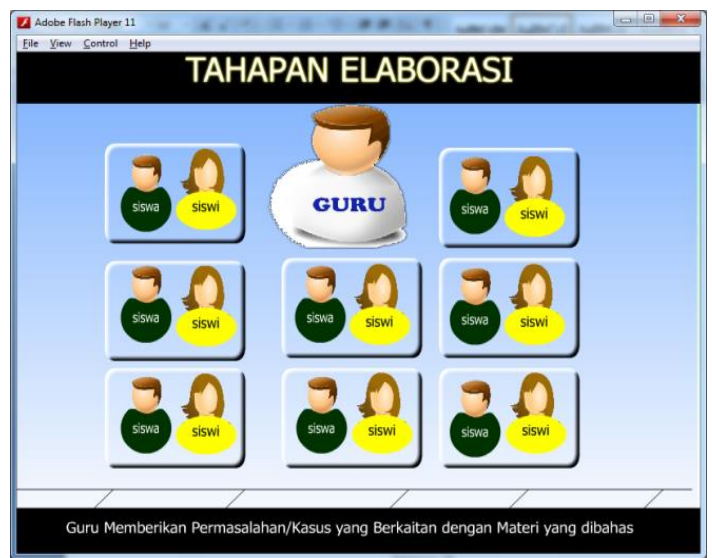

Figure 4. Step model of Simulation Interface. 


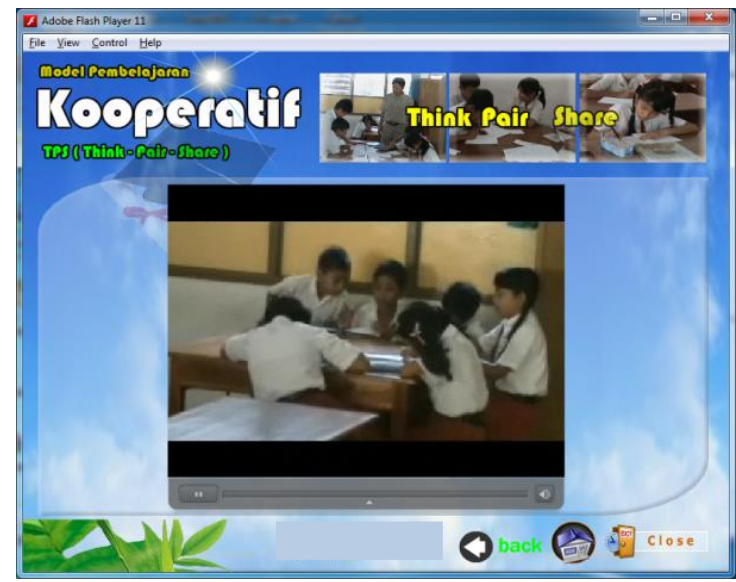

Figure 5. Video TPS Model Simulation Interface.

User experience is measured after using valid media on students who have already taken real PPL courses. Questionnaire responses consist of 5 points of Likert scale 1-5, so ideal score and ideal lowest score respectively is 25 and 5. The student response rate is 20,50. In general, it shows that the student's response is very positive to the simulation media of cooperative learning model. In detail, it can be seen in the table that in total $60 \%$ of the students responded very positively and $40 \%$ responded positively to the existence of simulation media cooperative learning model in micro teaching lectures, and no one responded negatively. If visualized in the form of a histogram like a Fig. 6.

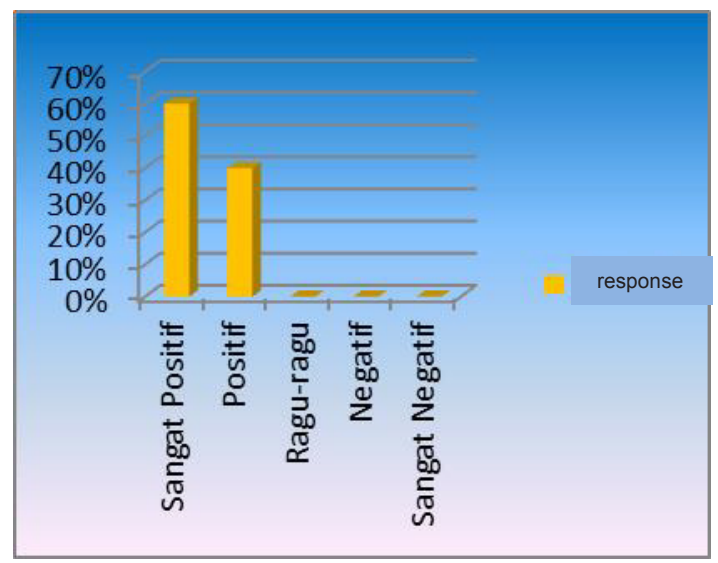

Figure 6. The Histogram of User Experience through Simulation media.

In the development of this simulation media, the accuracy of the use of design is very decisive design. In addition, the type and size of letters and color combinations are also important because a simulation media developed with flash requires a high imagination and ability to analyze to visualize something abstract to be concrete and interesting so that students interested and motivated to learn the material. During the development process has been through several revisions based on inputs provided by content experts, media and instructional design.

With a very positive response from students to the simulation media is expected to be able to improve the professionalism of prospective teachers in preparing before teaching to the real class. The result of this study are consistent with the result of research conducted 
by the [11] that students provided positive feedback regarding this educational innovation. This year, the development research that has been done is only done for the simulation process of cooperative learning model and limited trial to know the student's response to the developed software. The real experimental stage to further test the effectiveness of the use of simulation software of this cooperative learning model on the learning outcomes in PPL real will be done at the advanced stage of this research.

\section{CONCLUSION}

The Cooperative Learning Model Simulation is designed using Data Flow Diagrams (DFD) and implemented using flash 8 and can simulate three models of cooperative learning well, and student response to the development of model simulation Cooperative learning is very positive at $60 \%$ and positive by $40 \%$.

Suggestions for further research are: (1) It is necessary to develop more simulation of instructional media based on cooperative learning model to assist students who have abstraction ability that is less in abstract lecture materials, both educational and noneducational field especially in informatics; (2) The utilization of ICT in the learning process should still be implemented within the framework of learning objectives in accordance with the indicators of achievement, with no cause of learning conditions that tend to be considered like playing with the media itself; (3) To know how much influence or effectiveness simulation system that has been developed toward student achievement, it is necessary that the result of this research is followed up by doing further research through experimental research or action research.

\section{ACKNOWLEDGEMENTS}

This work was supported by the Daftar Isian Pelaksanaan Anggaran (DIPA) Universitas Pendidikan Ganesha.

\section{References}

1 I P. Wisna Ariawan, D.B. Sanjaya, and D.G.H. Divayana, IJARAI, Vol. 5 No.2 (2016).

2 Agustini. K, Proceeding,APTEKINDO, ISSN No. 1907-2066, Denpasar (2010).

3 I M. Ardana, I P.Wisna Ariawan, D.G. Hendra Divayana, IJEME, Vol. 7 No. 4 (2017).

4 D.G. Hendra Divayana, I M. Ardana, I P. Wisna Ariawan, JATIT, Vol.95. No. 9 (2017).

5 Rustaman, N., D, S., Yudianto, S.A., Achmad, Y., Subekti, R., Rochintaniawati, D., \& Nurjhani, M.. Common Text Book Strategi Belajar mengajar Biologi. Edisi Revisi., Bandung: JICA-IMSTEP-UPI (2003).

6 Ina Karlina, Pembelajaran Kooperatif (Cooperative Learning) sebagai Salah Satu Strategi Membangun Pengetahuan Siswa (2010).

7 Agustini K., Proceeding SNATIKA Vol 01 (2011).

8 Esther Zaretsky, SCI, Vol. 4 No. 4 (2006).

9 Dick W, Carey \& James O Carey. The Systematic Design Of Instruction, New Jersey: Pearson (2009).

10 Santyasa I Wayan. "Metode Penelitian Tindakan Kelas, Pengembangan, Korelasional, Kausal Komparatif, dan Eksperimen”, Lembaga Penelitian Universitas Pendidikan Ganesha, Singaraja (2009).

11 M.L. Cason, et al., J Nurs Educ, Vol. 54 No. 3 (2015). 